\title{
夕張川1898年洪水の 被災状況および汇濫形態の検証 \\ THE RECORD-SETTING 1898 YUBARI RIVER FLOOD: STUDY ON DAMAGE AND REPRODUTION OF FLOODING
}

\author{
鈴木 英一1 - 山口 里実 2 - 菊地 則雄 3 \\ Eiichi Suzuki, Satomi Y amaguchi and N orio Kikuchi \\ 1フェロー会員 北海道大学特任教授 大学院工学研究院 ( \\ 2正会員 北海道大学特任准教授 大学院工学研究院（产060-8628 札幌市北区北13条西8丁目） \\ 3正会員＼cjkstart株式会社ドーコン 河川環境部（テ004-8585札幌市厚別区厚別中央1条5丁目4-1）
}

The Y ubari River is a tributary of the Ishikari River, which flows through Central Hokkaido. In 1898, 30 years after the Meiji Government launched the policy of encouraging migration to Hokkaido, a historically disastrous flood struck the Ishikari River Basin. Of the 112 people killed in this flood throughout the Ishikari River Basin, 82 fatalities were in or near Kuriyama in the Y ubari River Basin, which is part of the Ishikari River Basin. No other recorded flood in the Ishikari River Basin has claimed as many victims. In Kuriyama Town, word of this disaster has been passed down in oral tradition and written records. However, because little hydraulic data is available to estimate the scale of the 1898 flood, including the flood discharge, the flood mechanism and damage have not been adequately investigated. This study aims to elucidate the mechanism of this flood through detailed examination of accounts of flood damage that have been orally transmitted for more than a century.

\section{Key Words: 1898 flood of Yubari River, The heaviest recorded flood damage, F lood flow, F lood simulation}

\section{1.はじめに}

石狩川は北海道の中西部を流れ，流域面積 $14,330 \mathrm{~km}^{2}$ を持つ一級河川である. 石狩川水系の一つである夕張川 は, 空知川・雨竜川に次いで三番目に大きな流域面積を 有する支川である.この夕張川流域の中でも図-1に示す 栗山町は人口 1 万 4 千ほぼの農業地域であり, 南部の角 田地区（以下角田村と記す）ではかつて歴史的な大洪水 に襲われ多数の死亡被害者が出ている1),2).

明治初期の北海道開拓開始から 30 年経った1898年，石 狩川全流域で死亡被害者112名を出寸大洪水が発生した. この1898年洪水を機に石狩川の治水事業に向けた調査が 開始されることになるが，その後の石狩川の洪水におい てこれほどまでに多くの死亡者を出した例はない，ここ で注目すべきは，石狩川全流域における死亡被害者数 112名の内82名が図-1に示寸夕張川流域の角田村および その近傍で被災したという事実である. 現在の栗山町で は，明治 31 年洪水の惨劇のうちいくつかが今もなお語り 継がれているだけでなく，鮮明な記録が数多くの文献と して残されている(1), 2). しかし, その一方で, 入植以来

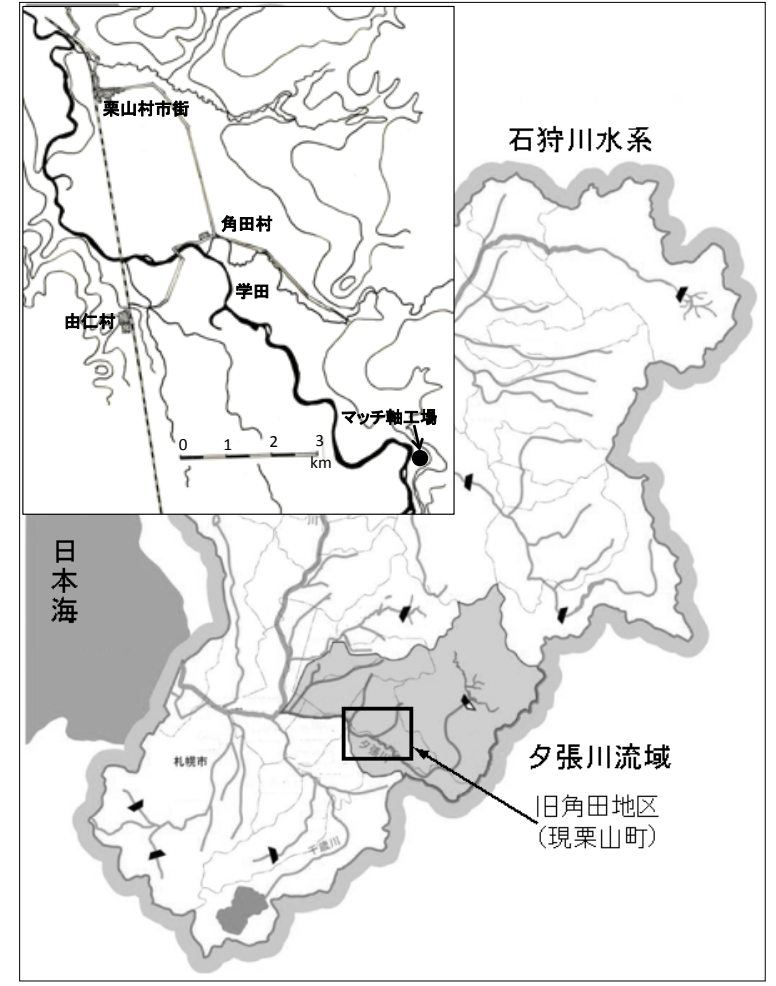

図-1 夕張川流域位置図 
開拓が順調に進んでいた矢先の不意の大洪水であったた めに, 流量など洪水規模の推定に必要な水理データの記 録はほとんど皆無である. 数多くの被苂状況が鮮明に記 録として残っているのにも関わらず，その汇濫現象や被 災要因は解明されずにいる. 本研究は，100年以上もの 間伝承され続けてきた当時の被災状況を詳細に検証し, 被災要因を解明することと後世への伝承を目的とする。

入植直後の1898年当時，角田村では河道も汇濫原もほ とんぞ原野に近い状態であり, 氾濫流は単に地形上の起 伏に従って流下していたものと考えられる. そのような 汇濫流がじのようにして82名もの犠牲者を出したのか. 近年, 数值解析技術の著しい発展に伴って汇濫解析の分 野でも比較的容易に汇濫流の再現計算が可能となり ${ }^{5}$, 国内外で洪水被害が発生すると，再発防止に向け汇濫解 析が積極的に行われるようになっている，その一方で， 河川整備が進むことで汇濫流によって死亡被害者の出る ような洪水災害は少なくなっており，実際に多くの死者 を出す汇濫流を検証するケースは少ない. しかし，近年 頻発する豪雨などの異常気象によって洪水被害に対する 危険性は今後増大していくであろう，過去に多くの死亡 被害者を出した洪水を詳細に検証することやこのような 被害が生じていたという事実を後世に伝えていくことは 今後の防災に対して重要である.

\section{2. 角田村における1898年洪水被災状況}

\section{（1）角田村（現栗山町角田地区）}

角田村を流れる夕張川は，上流部が山地に挟まれた狭 窄部となっており, 角田村上流では河岸段丘によって若 干の土地が開けている. 角田村より下流部は北側の栗 山・岩見沢丘陵と南側の馬追丘陵に挟まれていて，上流 ほどではないが幅約 $5 \mathrm{~km}$ 程度の狭窄部となっている。こ の地区における平野部では1898年当時は既に田畑への開 墾が進んでいたとされており，後述するように一部樹林 帯を除いてほぼ全域に田畑が広がっていたと考えられる。

この地区内では現在に至るまでほとんど河川整備が行 われていないにも関わらず，近年では大きな洪水は発生 していない.この地区の下流側では大規模な夕張川の河 道切換えが1941年に行われ，千歳川に注いでいた夕張川 は直接石狩川へ流れ出ることとなった。 この地区の上流 側では農業用水のための大夕張ダムが1961年に, 川端ダ ムが1963年に設置された。.また，この地区は砂利採取が 特に積極的に行われた地域であったために大量の土砂が 搬出されたと言われており，これによって河床が著しく 低下したと考えられる.

図-2に2003年現在と最も古い測量データである1953年の 平均河床高の縦断形 ${ }^{1)}$ を示寸. 図を見ると, 特に夕張橋 付近の平野部で著しく河床が低下しているのがわかる. このように，この地区の治水安全度が向上した要因はい

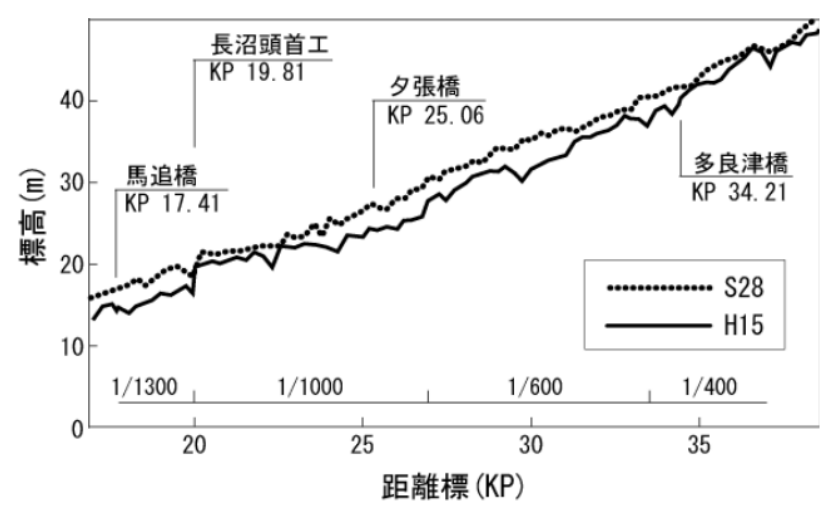

図-2 夕張川河床縦断図 (1953, 2003)

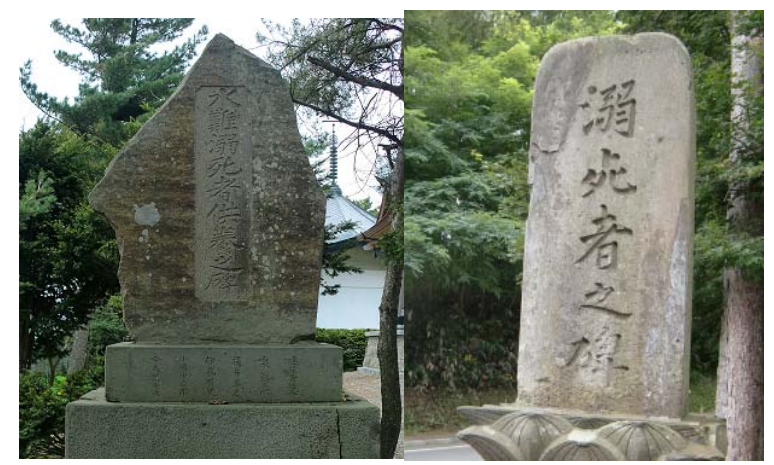

図-3 明治31年洪水慰霊碑（角田方田寺, 由仁大乗寺）

くつか考えられるもののその要因は明らかではない．

\section{（2）当時の被災状況}

1898年洪水の被災状況については，参考文献1，2)を始 め多くの文献でその様子が生々しく記録されている.さ らに，著者らは現地で聞き取り調查を行い，文献に記録 されている被害事象について被災個所を明らかにした。 文献と聞き取り調查の結果に基づいて当時の主な被災事 象をまとめると次のとおりである.

a）マッチ軸工場の流失2)

以下に当時の新聞記事から抜粋し要約する.

[9月6日の午後 9 時頃］夕張川沿いの多良津に建てら れたマッチ軸工場に住む者が川岸に出て様子を見に 行ったが，平水よりも三尺 $(90 \mathrm{~cm})$ 程の増水で案ず るに及ばないと寝に就いた. [午後11時頃］轟々たる 響きに目覚めて都外一出ると, 周囲は洪水で漲って おり，その工場に宿泊していた家族を含め35名が避 難しようとしたが低地に立っていたため避難するこ とができず，やむなく工場の屋上に上り，救助を求 め叫んでいた。 しかし，急激な流れと共に大木や樹 根が家にぶつかる。 [翌朝5時半］遂に，工場は三十 余人を屋根に乗せたまま浮き上がり，数キロ流され た先で転覆し34名が死亡し，1名だけが阿野呂学田に 立つ樹木にしがみつき運よく助かった。

図-3はマッチ軸工場の溺死者を供養する慰霊碑であり， 角田の方田寺には裹面に溺死者の名前と年齢が，由仁の 大乗寺には裏面に当時の状況が刻まれている. 


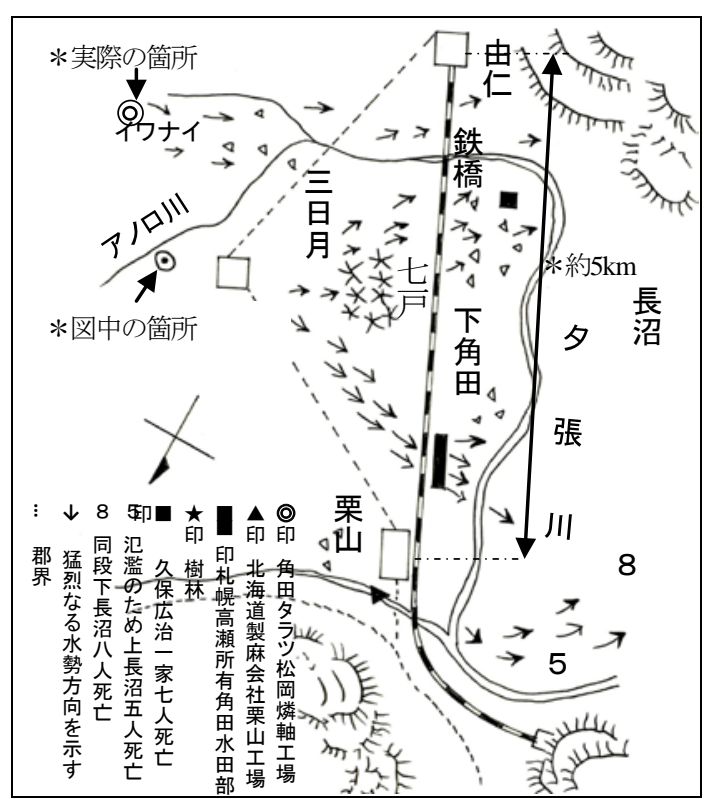

図-4 1898年洪水による高速流発生状況 ${ }^{2}$

(*印 : 当時の新聞に筆者が記入)

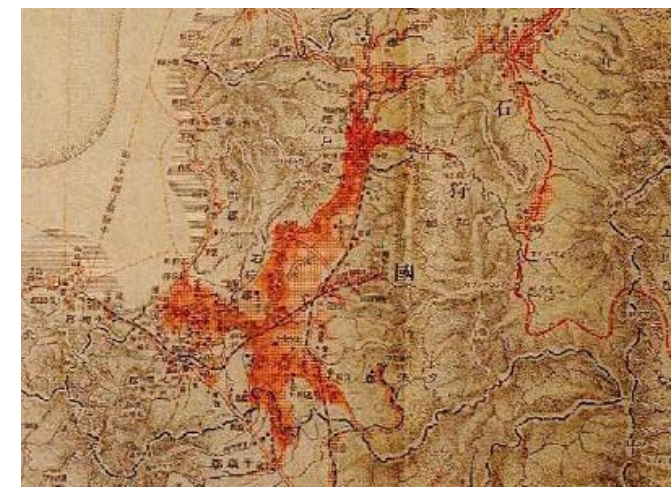

図-5 1898年洪水浸水域図（石狩川流域）

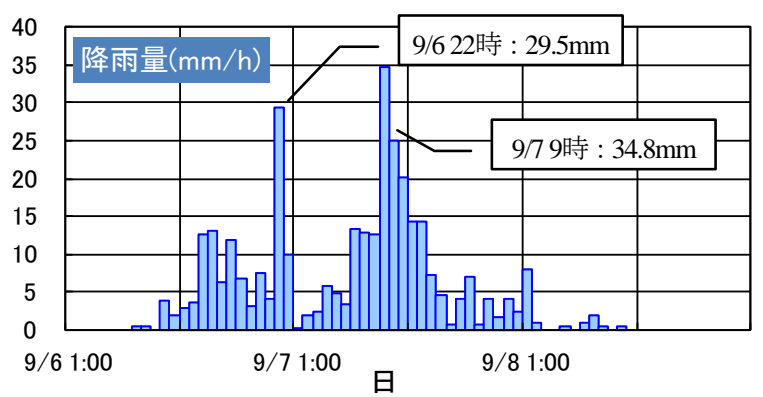

図-6 1898年洪水雨量（札幌観測所）
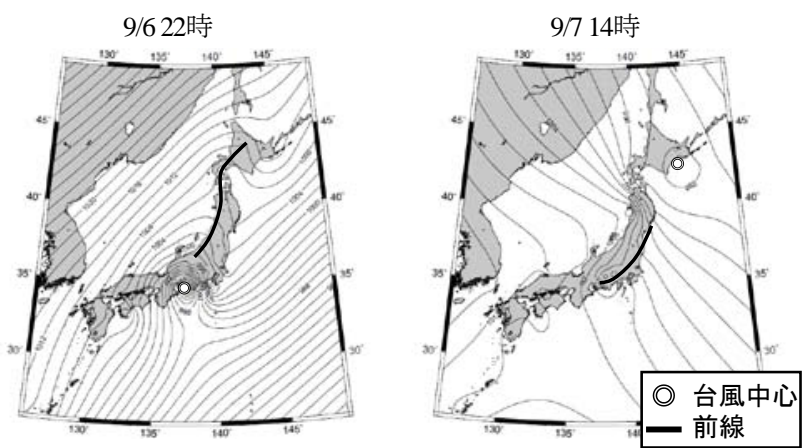

図-7 1898年9月洪水の天気図

\section{b） 高速流の発生 ${ }^{3)}$}

下角田では高速流に一家7人が吞みこまれて死亡する 被害や栗山駅付近で鉄道が流出する被害があったと記録 されている．当時の新聞によると高速流の発生状況が図 -4のように記されている. 当時七戸と三日月の間に樹林 帯があったといわれており，この樹林帯に夕張川の流れ と阿野呂川の流れがぶつかり樹林帯によって流れが 2 分 され高速流が発生したと記述されている.

\section{c) 被災状況および洪水時の様子1)}

当時の降雨および洪水の状況を時系列でまとめると以 下のとおりである.

・5日 夕方より降雨

・6日 終日大雨

- 6 日21時頃 多良津川岸で平水より三尺 $(90 \mathrm{~cm})$ 増水

・6日23時頃 多良津付近で汇濫が始まり屋根に避難.

・7日5時半頃 マッチ軸工場が流される

・7日23時 栗山で最大水深，船で救助を行う

本洪水によって，角田村は流失家屋62戸，破壊48戸，浸 水488戸であり, 農作物はほぼ壊滅した。 この洪水の石 狩川流域の浸水地域を図-5に示す。

\section{3. 洪水流量の推定}

\section{（1） 1898年当時の降雨データの推定}

洪水汇濫計算を行うため, 夕張川等からの洪水流量を, 当時の降雨記録，天気図および文献1) から推定する.

1898年9月洪水時には札幌測候所で $158 \mathrm{~mm} / 3$ 日，旭川 測候所で $163 \mathrm{~mm} / 3$ 日の降雨が記録されている4)。札幌測 候所の降雨波形を図-6に，北海道付近の天気図の時間変 化を図-7に示す。降雨波形は2山となっており初期の降 雨は前線の通過由来であり, 2 山目は台風に起因すると 考えられる.

当時の夕張川流域の降雨の推定に当たっては，過去10 年以内の天気図データの中から台風の通過経路と前線に よる前期降雨が類似している2003年8月洪水の事例を出 した. この洪水における札幌と夕張川流域の降雨量の比 を用いて1898年洪水時の夕張川流域の降雨量を推定した.

\section{（2）流出計算}

前節の夕張川流域雨量を用いて貯留関数法 ${ }^{51}$ による流 出計算を行い, 夕張川と阿野呂川の流量を設定した. 流域

$$
\begin{aligned}
& \text { 運動の式 } \cdots \mathrm{S} 1=\mathrm{Kq}_{\mathrm{i}}^{\mathrm{p}} \\
& \text { 連続の式 } \cdots \frac{\mathrm{ds}}{\mathrm{dt}}=\mathrm{Re}-\mathrm{q}_{\mathrm{i}}
\end{aligned}
$$

河道

$$
\text { 運動の式 ‥ } \mathrm{S} 2=\mathrm{f}\left(\mathrm{Q}_{0}\right)
$$


表-1夕張川流域定数(単位: 面積 $\mathrm{km}^{2}$, 距離 $\mathrm{km}$ )

\begin{tabular}{|c|c|c|c|c|c|c|}
\hline 流域 & 面積 & 域長 & 勾配 & 河道長 & 左勾配 & $\mathrm{P}$ \\
\hline 1 & 433 & 22 & $1 / / 21$ & - & - & - \\
\hline 2 & 359 & 29 & $1 / / 34$ & 5 & $1 / 450$ & 0.4 \\
\hline 3 & 53 & 6 & $1 / 34$ & 14 & $1 / 536$ & 0.8 \\
\hline 4 & 80 & 13 & $1 / 37$ & - & - & 一 \\
\hline
\end{tabular}

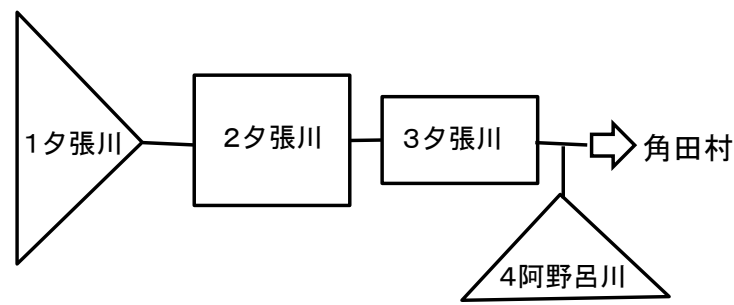

図-8＼cjkstart貯留関数法計算模式図

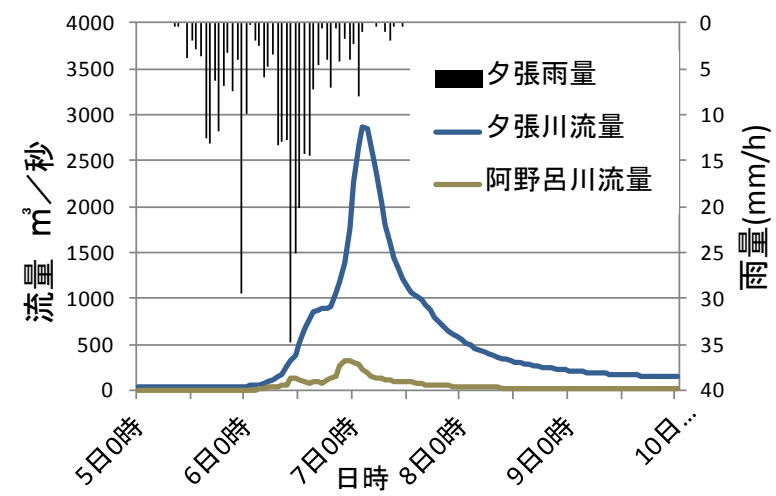

図-9 1898年洪水流量ハイドログラフ

$$
\text { 連続の式 } \cdots \frac{\mathrm{ds}}{\mathrm{dt}}=\mathrm{Q}_{\mathrm{i}}-\mathrm{Q}_{0}
$$

ここで, S1 : 貯留高 $(m m), K, P,:$ 貯溜関数定数, $q_{i}$ : 流 出高 $(\mathrm{mm} / \mathrm{hr}), \mathrm{Re}$ : 有効降雨 $(\mathrm{mm} / \mathrm{hr}), \mathrm{Qi}$ : 河道流入流 量 $\left(\mathrm{m}^{3} / \mathrm{s}\right), \mathrm{Q}_{0}$ : 河道流出流量 $\left(\mathrm{m}^{3} / \mathrm{s}\right), \mathrm{S} 2$ : 貯留高 $\left(\mathrm{m}^{3}\right)$. 計算模式図を図-8，設定した定数を表-1，2に示寸．計 算結果として得られた角田村へ流入する夕張川および阿 野呂川の流量ハイドログラフを図-9に示寸．ピーク流量 は約2,800m3/sであり，この地点における現在の基本高 水流量と同程度の流量である.

\section{1898年洪水の再現計算}

前章で求めた流量ハイドログラフを用いて，1898年洪 水時の角田村付近での汇濫について再現計算を試夕た.

\section{（1）氾濫モデルの概要}

計算は，河道を一次元不定流，氾濫原を二次元不定流 で計算するものであり，河道から氾濫減への越流量は河 道水位と汇濫原の水位差より越流公式で算定する6).

\section{（a）汇濫域モデル}

汇濫原での2次元不定流計算式は次式で表わされる.
表-2 夕張川流域定数

\begin{tabular}{|c|c|c|c|}
\hline 流域 & $\mathrm{K}$ & $\mathrm{P}$ & $\mathrm{TI}$ \\
\hline 1 & 49 & 0.33 & 2.5 \\
\hline 2 & 56 & 0.33 & 3.5 \\
\hline 3 & 40 & 0.33 & 0.6 \\
\hline 4 & 44 & 0.33 & 2.9 \\
\hline
\end{tabular}

連続式 $\quad \frac{\partial h}{\partial t}+\frac{\partial(h u)}{\partial x}+\frac{\partial(h v)}{\partial y}=0$

$x$ 方向の運動方程式

$$
\frac{\partial \mathrm{M}}{\partial \mathrm{t}}+\mathrm{u} \frac{\partial(\mathrm{uN})}{\partial \mathrm{x}}+\mathrm{v} \frac{\partial(\mathrm{vM})}{\partial \mathrm{y}}=-\mathrm{gh} \frac{\partial \mathrm{H}}{\partial \mathrm{x}}-\frac{\tau_{\mathrm{xb}}}{\rho}
$$

y方向の運動方程式

$$
\frac{\partial \mathrm{N}}{\partial \mathrm{t}}+\mathrm{u} \frac{\partial(\mathrm{uN})}{\partial \mathrm{x}}+\mathrm{v} \frac{\partial(\mathrm{vN})}{\partial \mathrm{y}}=-\mathrm{gh} \frac{\partial \mathrm{H}}{\partial \mathrm{y}}-\frac{\tau_{\mathrm{yb}}}{\rho}
$$

ここで，u，v : 深さ方向 $\mathrm{z}$ に平均したx方向，y方向の流 速, $h$ : 水深, $H$ : 水位, $M=u h, N=v h: x$ 方向およびy方 向の流量フラックス, $\tau_{\mathrm{xb}}, \tau_{\mathrm{yb}}$ : 底面に作用寸るx方向, y方向の剪断応力である.

汇濫計算対象区域は, 夕張川上流端を多羅津橋下流の マッチ工場を含む34.5k地点とし，下流端を岩見沢・栗 沢丘陵と馬追丘陵に挟まれる狭窄部下流側の14.0k地点 とした．支川は，夕張川25.75kに合流する阿野呂川を考 慮した.

計算格子サイズは $100 \mathrm{~m}$ とし，格子数は東西 $109 \times$ 南北 140 として計算格子を構成する. 地盤高はLPデータより 格子中心位置の地盤高を設定した. また氾濫域の標高が 50m代であるため，地盤高が70m以上の格子は計算から 除外した.

粗度係数に関しては，昭和51年の国土数值情報より土 地利用を推定し，汇濫シミュレーションマニュアル ${ }^{51}$ の 汇濫原粗度係数設定より, 農地を粗度係数 $n=0.060$, 道 路を $\mathrm{n}=0.047$, その他を $\mathrm{n}=0.050$ として加重平均式により 求めた底面粗度係数を用いた。

\section{(b) 河道モデル}

1898年の夕張川および阿野呂川の河道形状は，現在と は大きく異なるため以下のように河道モデルを作成した 河道平面形状 : 夕張川の旧河道は市町村境界に沿ってい たと考えられるため, 行政界を旧河道として設定した.

断面形状: 当時の河道データが無いため, 川幅は未改修 区間を参考に，夕張川を $100 \mathrm{~m}$ ，阿野呂川を $50 \mathrm{~m}$ と設定し た. 形状は河床高を考慮して三角形断面で近似した.

最深河床高および河床勾配 : 現夕張川の最深河床高を用 い，延長を旧河川延長に伸ばし，河床勾配を設定した.

粗度係数 : 阿野呂川の現況の河床材料は2 $5 \mathrm{~cm}$ であり, 「美しい山河を守る災害復旧基本方針」 ${ }^{81}$ より河床の粗 度係数 $n=0.029$ とした. 夕張川も同じ值とした.

また，本解析対象範囲において河道は無堤とした。 


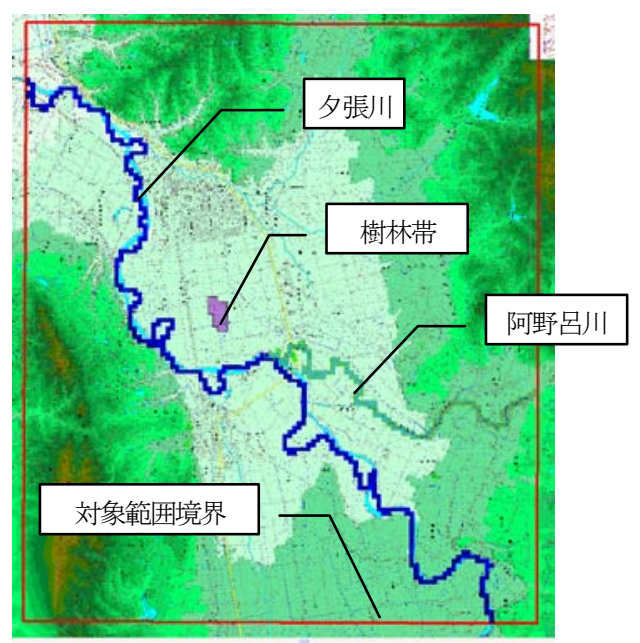

図-10 氾濫計算対象範囲および対象河道

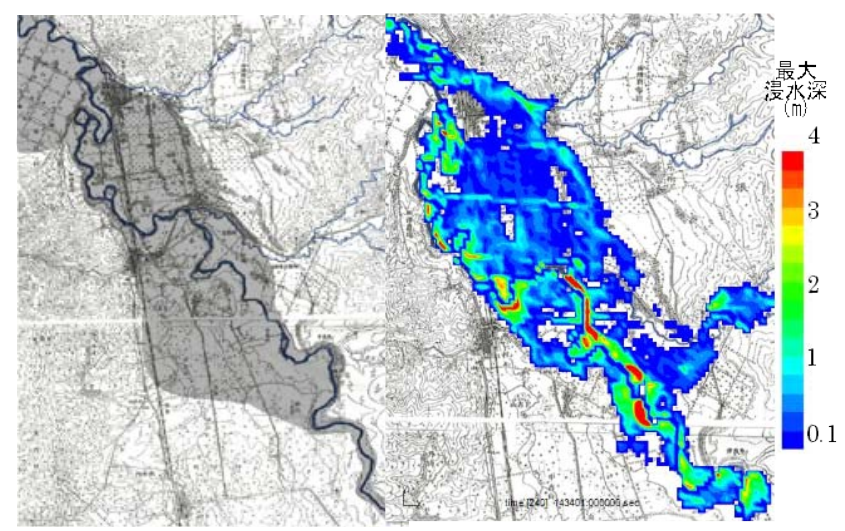

図-11 1898年洪水栗山町浸水域図および再現計算による最大 浸水深コンタ図

\section{（c）下流端水位}

夕張川下流端は前述の通り 14.0k（岩見沢・栗沢丘陵 と馬追丘陵に挟まれる狭窄部下流側）に設定した。 14.0k 付近の地盤高は $15 \mathrm{~m}$ 程度であり, これは狭窄部上 流側である17.0k付近での地盤高 $19 \mathrm{~m}$ 程度と比較して $5 \mathrm{~m}$ 程度低いことから14.0kでの水位は上流一影響を及ぼさ ないと考えられる。よって下流端水位は地盤高同様の 14.5mと設定した.

\section{(d) 樹林帯の設定}

下角田で発生した高速流による流況の再現を試みるた めに，当時七戸と三日月の間にあった樹林帯を非透過型 の構造物として図-10に示すように設定した.

\section{（2）1898年洪水の再現結果}

浸水実績図および氾濫計算による最大浸水深コンタ図 を図-11に示寸．算結果と浸水実績図を比較寸ると，夕 張川右岸側の角田村や栗山村の汇濫の広がりは同様の傾 向を示しある程度再現できているものと考える. また， 実績図上流左岸側は支川由仁川からの汇濫と推察するが， 計算では由仁川の氾濫は考慮していない，また支川阿野 呂川からの汇濫は汇濫図では記載されていないが，阿野

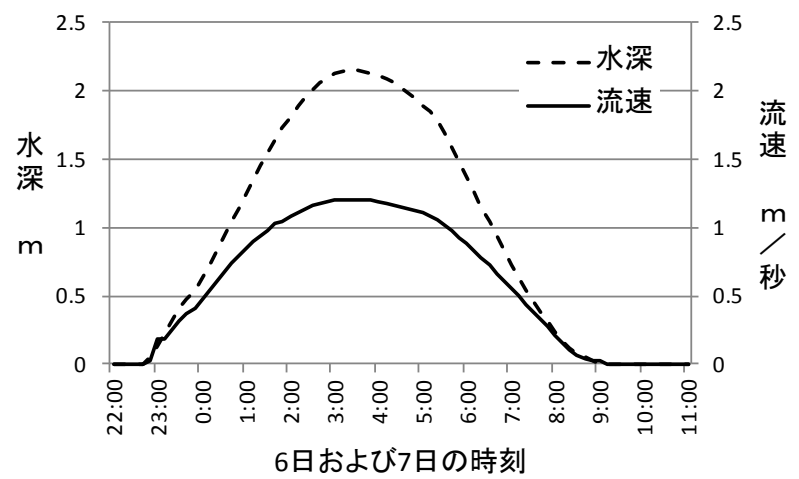

図-12 計算による多良津地点の水深と流速の変化

呂川では近年の洪水でも氾濫が発生しており，当時の氾 濫図では記載されていないものと考えられる.

\section{（3）汇濫流の広がり}

マッチ軸工場のあった多良津地点の計算結果の水 深と流速を図-12に，また計算による氾濫流の様子 を図-13に示し，2章で整理した洪水の状況と比較 する.

・6日21:00 計算結果では, 夕張川は増水してはい るが多良津地点では汇濫はまだ発生しておらず,

「夕張川で平水より三尺 $(90 \mathrm{~cm})$ 位の増水」という記 録と同様の状況が再現されている.

-6日23:00 計算結果では, 当該地点付近で夕張川 からの汇濫が始まり, 汇濫水深も増加し始めている。 記録では「避難せんと思えじ，蛇行した低地に建ってい たため避難の道は断たれ，止むなく屋上に昇り」となっ ている．急激に水が地表を走り始めている状況で，深夜 の暗闇の中であることも勘案すると妻や幼い子供を連れ ての避難は困難であったと考えられる.

・7日5:30 計算結果では，工場のあった多良津で最大 水深約 $2 \mathrm{~m}$, 流速 $1 \mathrm{~m} / \mathrm{s}$ 以上という状況が示されており, この状況の中で三間 $\times$ 十間 $\left(\right.$ 約 $\left.97 \mathrm{~m}^{2}\right)$ の木造の工場が流 れ出すことは十分に考えられる. 記録では「急激な流れ と大木樹根が流れ来たって家にぶつかる. その度毎にぐ らぐらと動く, 朝5 時半頃, 遂に家屋は浮き上がった. と, 見る間に矢のように流れ出し, 僅かな時間の後, 顛 覆して，屋上の人々は寸時に水中に投げ出された.」と なっており, 夕張川の流心に向かって流されていったも のと推定できる.

・7日23:00（下流の栗山村で洪水ピーク時） 計算結果 で栗山の水深が最大になるのは7日7:00であり, 計算結 果は実際の記録よりも洪水ピークまでの時間が短くなっ ている. 浸水の状況については, 「栗山で最も水の高か りしは七日夜十一時頃にして市街地は一，二寸 $(3 \sim 6 \mathrm{~cm})$ にして床上に達せざりし」と記録されている，計算でも， 栗山町市街部には浸水は見られず, 近傍では $2 \mathrm{~m}$ 程度の 浸水が生じており，記録と同様の状況が再現されている。 このように汇濫状況については, 計算結果は当時の記録 


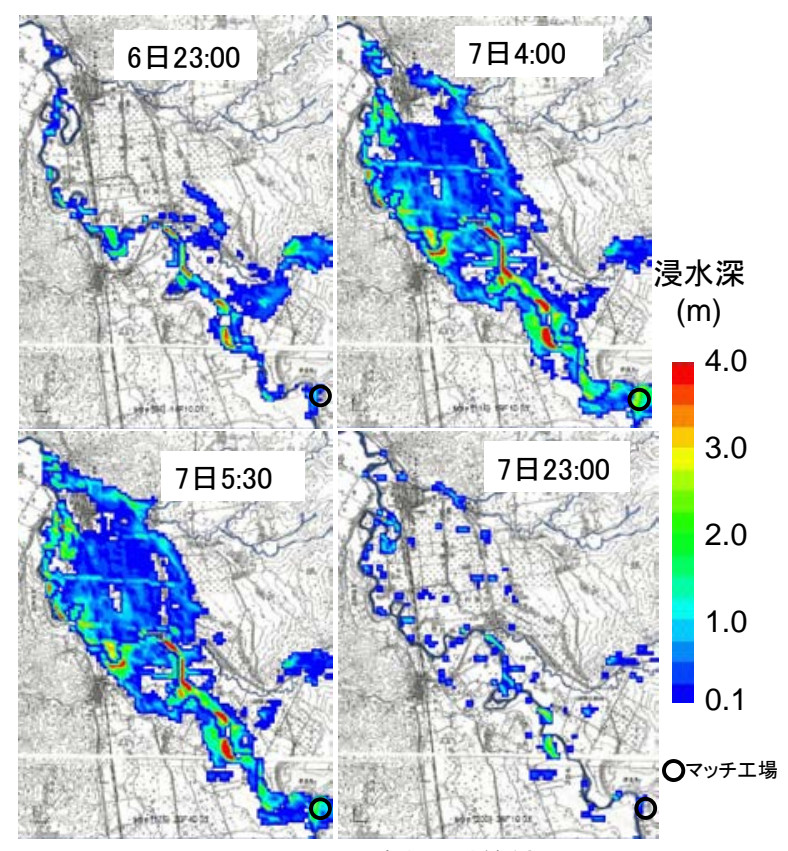

図-13 氾濫水深計算結果

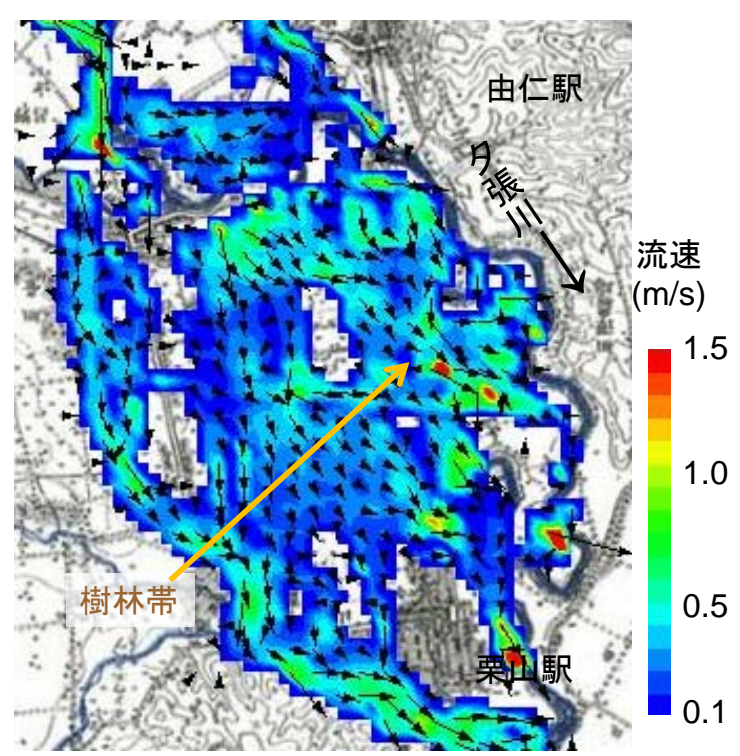

図-14計算による7日5時の流速状況

をある程度良好に再現できている，しかし，洪水の経過 時間が当時の記録より早くなっている.これは雨量や下 流端水位条件や粗度の推定に不確定な要素が多く当時の 状況と必ずしも同じ条件で設定できているとは限らない ためと考えられる.

\section{（4）高速流の発生}

図-4に示した資料 () には「アノロ方面の水勢は，角田 を外抜きて字七戸・三日月等を真っ向に衝き，大破壊 を演じて突進せんとせしが，樹林の防ぐるところとなり， 数千の樹木を倒して激流二分し」と記録されており, こ の二分した高速流の下流側で20数名, 対岸側で15名の死 者を出したとされている.

図-14に示すように汇濫原を流下してきた洪水流が中 央の樹林帯により二分されている状況が計算でも再現さ
れてはいるが，計算で得られた流速は $0.8 \mathrm{~m} / \mathrm{s}$ 程度と特に それほどの高速流ではなかった，それでも樹林帯で二分 された流れが比較的高速になる傾向は計算でも確認され ることから，樹林帯の位置や規模によっては樹林帯とい う障害物のために流れが収束して高速流が発生し被害を 大きくしたことは十分に考えられる.

\section{5. おわりに}

本研究では, 過去の歴史的洪水の検証および伝承を目 的とし，1898年に夕張川流域栗山地区（角田村）を襲っ た洪水について洪水規模の推定と汇濫計算による再現を 行った. 当時の主な被災状況は, 夕張川沿いのマッチ工 場が34名の従業員とともに流失したことと樹林帯で二分 された高速流によって多くの死者が出たことである. 推 定された洪水規模は計画高水流量に匹敵する規模であり， その流量下で再現計算を行ったところ，川沿いの工場が 流失する可能性が十分に考えられる規模であることが検 証された. また, 樹林带周辺において比較的高速な流れ が再現され，樹林帯の位置や規模によっては樹林帯とい う障害物のために流れが収束して甚大な被害を出すよう な高速流が生じる可能性のあることが確認された. 本洪 水の再現計算は，ほとんど全ての条件を推定するしかな く不確定要素を多く含んでいるにもかかわらず，汇濫状 況についてはある程度良好に再現できており，伝承する ためのツールとして充分に活用できると考えられる.

2011年現在，上流に治水目的を持つ夕張シューパロダ ムを建設中である. ダム完成後にはこの地域は治水安全 度が飛躍的に向上寸ることとなる．しかし，僅か1世紀 前にこのような大きな被害を被った地区であり，潜在的 に洪水が発生する特性は失われていない. 本研究のよう に，既に伝説化し，ほとんど忘れられている悲惨な洪水 がどのように発生し，なせ被害が拡大したのかを，科学 的に解明することは，現在に生きる住民に警鐘を与え， 防災力を向上寸るうえでも重要であると考えられる.

\section{参考文献}

1) 石狩川開発建設部 : 夕張川大横断測量成果, 1953, 2003.

2）松田光春 : 明治31年（新聞報道による北海道大洪水の惨状）, 2006.

3) 石狩川開発建設部 : 石狩川の流れ，2000.

4) 気象庁天気図 : JMA WEATHER CHARTS Vol. 02, 2005.

5）日本河川協会 : 建設省河川砂防技術基淮（案）同解説，調査 編, pp89 91, 2008.

6) 建設省土木研究所: 氾濫シミュレーションマニュアル，1996. 7）国土交通省: 美しい山河を守る災害復旧基本方針，2006. 